\title{
Etnografi Komunikasi Tata Cara Bertutur Masyarakat Suku Padoe
}

\author{
Pancana Beta, Besse Herdiana, Rinni Salvia \\ Fakultas Keguruan dan Ilmu Pendidikan \\ Universitas Cokroaminoto Palopo \\ pancanabeta@uncp.ac.id, besse@uncp.ac.id, Rinnioppa@gmail.com
}

\begin{abstract}
Abstrak
Konsep tentang etnografi komunikasi berbicara tentang masyarakat dan segala tindakan kebudayaan berupa kejadian yang diekspresikan masyarakat dengan bahasa. Relevansi antara bahasa dan etnografi terlihat pada ekpresi kebudayaan yang dijelaskan melalui peristiwa bahasa. Etnografi mengkaji peranan bahasa dalam perilaku komunikatif masyarakat, cara bagaimana bahasa digunakan dalam masyarakat yang berbeda kebudayaan. Tulisan ini menjelaskan etnografi masyarakat suku Padoe di Desa Tabarano Kecamatan Wasuponda berdasarkan teori Hymes. Etnografi komunikasi berupa tata cara bertutur masyarakat suku padoe mengacu pada penggunaan bahasa kasar dan bahasa halus yang penggunaannya berlandaskan etika yang disesuaikan dengan variasi bahasa, konteks, situasi, serta lawan tutur.
\end{abstract}

Keywords: Etnografi komunikasi, tuturan

\section{Pendahulan}

Etnografi sebagai bagian sub disiplin ilmu lebih banyak berfokus pada hubungan kelompok sosial atau pelaku budaya dengan interaksinya. Kelompok sosial ini adalah sekumpulan individu yang terjalin dan berinteraksi melalui subjek kolektif masyarakat. Konsep etnografi secara umum berhubungan dengan budaya dan masyarakatnya. Dalam penjelasan Malinowsky (dalam Fatchan, 2015:10) menegaskan bahwa tujuan utama etnografi adalah untuk memahami suatu pandangan hidup dari sudut pandang penduduk asli dalam hubungannya dengan kehidupan, untuk mendapat pandangannya mengenai dunianya.

Pandangan dunia yang menurut Malinowsky tentu saja tidak bisa dipahami dengan begitu saja tanpa bahasa sebagai medium penjelas. World of view akan dipahami dengan baik dengan melihat interaksi yang terjalin antara subjek kolektif masyarakat. Pada bagian inilah etnografi komunikasi mengambil bagian penting. Etnografi komunikasi wilayah objeknya berfokus pada pemakaian bahasa dalam penuturan atau lebih luas lagi yaitu komunikasi yang menggunakan bahasa. Dalam pengertian yang lebih kompleks istilah etnografi komunikasi yang diperkenalkan oleh Hymes mengambil konteks suatu guyub atau komunitas atau jaringan orang-orang kemudian meneliti kegiatan komunikasinya secara menyeluruh, sehingga tiap penggunaan saluran atau kode komunikasi selalu merupakan bagian dari khasanah komunitas yang diambil oleh para penutur.

Masyarakat suku Padoe merupakan salah satu dari suku yang berdiam di daerah Kabupaten Luwu Timur Provinsi Sulaewesi Selatan, suku ini tersebar di Wasuponda, Malili dan Sorowako.Mereka banyak tersebar di daerah pegunungan dan 
lembah di Luwu Timur dengan populasi yang diperkirakan sekitar 18.000 orang.Dalam bahasa setempat arti dari "Padoe" yaitu "orang jauh".Mayarakat suku Padoe memiliki adat istiadat yang tertulis dalam buku "Hukum Adat Padoe".

Padoe memiliki keunikan bahasa.Keunikan bahasa ini terdapat pada dialek yang beralun-alun yang khas.Dalam bahasa ini terdapat dua suku kata yang memiliki satu arti contohnya oiyo kee yang artinya iyakah dan ombio kake yang berarti bagaimanakah.Selain dua suku kata ada juga yang satu kata yang memiliki satu arti sepereti meawa yang berarti tertawa dan meiwi berarti menangis.Dan masih banyak suku kata yang lainnya.

\section{Pembahasan}

\section{Tata Cara Bertutur Masyarakat Padoe}

Dalam berbahasa atau bertutur dalam suatu budaya diatur sesuai dengan budaya tersebut. Baik itu dari segi gaya, norma, nilai, sikap, konteks, dan lainnya. Tata cara bertutur dalam suatu masyarakat mengandung gagasan peristiwa komunikasi di dalam masyarakat tutur. Mengandung pola-pola kegiatan tutur sehingga kompetensi komunikatif seseorang mencakup tentang pola itu. Tata cara itu mengacu pada hubungan antara peristiwa tutur, tindak tutur dan gaya disuatu pihak dengan kemampuan dan peran seseorang konteks dan instituasi, serta kepercayaan nilai, sikap, dan pihak lain (Sumarsono, 2014:319).

Tata cara bertutur dalam konteks etnografi merujuk pada penggunaan bahasa dalam interaksi disertai dengan latar belakang budaya sosialnya. Masyarakat Suku Padoe merupakan salah satu suku asli yang mendiami daerah Luwu Timur khususnya Kecamatan Wasuponda. Suku ini memiliki bahasa yang digunakan sebagai alat interaksi dalam kehidupan sehari-hari Penggunaan bahasa Padoe ini tentu memiliki tata cara tersendiri baik itu tertulis maupun tak tertulis yang dipatuhi secara menyeluruh oleh pengguna bahasa. Aturan berbahasa ini berlandaskan pada etika dalam berkomunikasi

\section{Norma Berbahasa Masyarakat Padoe}

Norma dalam pengunaan bahasa Padoe ini berlandaskan pada etika prilaku yang berlaku dimasyarakat. Dalam berbahasa penutur harus pandai memilih kata atau tuturan yang disesuaikan dengan kondisi, lawan tutur, serta situasi.Bahasa Padoe dibagi menjadi 2 bahasa, yakni bahasa kasar dan halus.Bahasa halus yakni bahasa yang digunakan dalam situasi resmi ataupun santai dan merupakan bahasa yang sopan.Sedangkan bahasa kasar merupakan bahasa yang digunakan pada variasi akrab.Perbedaan dari kedua jenis bahasa ini tidak hanya terletak pada kata dan struktur kalimat tapi juga pada penggunaan bahasa.Hal ini dapat dilihat pada contoh ujaran di bawah.

“ mingi lumeko ai moterioke iiko?" (bahasa kasar)

(anda ingin pergi ke mana?)

“minggi lumeko ai inderioke iikomiu?”( bahasa halus) 
(anda ingin pergi ke mana?)

Kedua ujaran diatas sama-sama bermakna "anda hendak kemana?" namun memiliki perbedaan pada kata, konteks, dan situasi. Kata "meterioke" ujaran bahasa kasar memiliki makna yang sama dengan kata "inderioke" pada ujaran bahasa halus yaitu "kemana".Penggunaan kedua kata ini disesuaikan sebagaimana dengan penggunaan bahasa halus dan bahasa kasar.Kata "meterioke" digunakan pada variasi bahasa akrab saja dan kata "inderioke" bisa digunakan di semua variasi bahasa.Pada ujaran bahasa halus ditambahkan kata "miu" pada kata "iiko" agar terdengar lebih halus dan sopan.

Tabel. 1. Perbedaan bahasa kasar dan halus pada bahasa Padoe

\begin{tabular}{lll}
\hline No & \multicolumn{1}{c}{ Kasar } & \multicolumn{1}{c}{ Halus } \\
\hline 1 & Spontaan dan singkat. & Lebih panjang \\
2 & Tidak memiliki kata kiasan & Memiliki kata kiasan \\
3 & Intonasi tinggi dan keras & Intonasi rendah dan tegas \\
4 & Tidak terikat aturan khusus & Terikan aturan \\
5 & Pengucapan kata lebih cepat & Pengucapan kata lebih lambat \\
6 & Terjadi tumpang tindih tuturan & Berbicara secara bergiliran, orang tua \\
& & didahulukan. \\
7 & Digunakan di variasi bahasa & Digunakan di segala variasi bahasa \\
& keluarga dan akrab & \\
\hline
\end{tabular}

Pembendaharaan kata yang kurang atau sedikit, menjadi salah satu hambatan dalam perkembangan bahasa ini. Disebabkan tidak adanya pembukuan dari pendahulu serta para penutur atau pengguna bahasa yang semakin berkurang.Hal ini juga berdampak pada aturan pengunaan bahasa yang tidak lagi kompleks seperti dahulu.Bahasa yang sangat halus hanya digunakan pada acara adat saja, meskipun masih dianggap kurang efIsien dalam penggunaannya dibandingkan dengan di masa lampau.Terlebih lagi dengan bahasa kasar yang penggunaanya tidak lagi terikat dengan aturan khusus.

\section{Variasi Bahasa}

Pada variasi resmi masyarakat Suku Padoe menggunakan bahasa Padoe halus misalnya digunakan di upacara adat pernikahan, acara adat orang meninggal, rapat adat, acara adat, serta surat menyurat dalam acara adat. Penggunaan bahasa ini sangat sopan, intonasi lebih rendah dengan nada bicara lambat namun tegas. Tidak boleh berbicara apabila belum diperbolehkan.Serta harus memperhatikan kata-kata yang pantas untuk diucapkan. Bila ada salah perkataan dan menyebabkan konflik maka akan dihukum sesuai aturan adat yang berlaku. Misalnya pada surat undangan di bawah ini. 
Jurnal Onoma: Pendidikan, Bahasa dan Sastra PBSI FKIP Universitas Cokroaminoto Palopo Volume 6 Nomor 1
ISSN 2443-3667 (print)

ISSN 2715-4564 (online)

Tabe.

Petia.......

Ai poiangamiu

Merongga aroa po'unde kaa pompelakai, ki hawe komiu petia mowawo io pompo hawe kaa pompeboi ndi ikomiu kimbuano kano nio tempomiu hawe ai acara "tepotowo'a petia" (lelenggae, kumonooio pompasara mami keluarga ,oposombori ana mami ai ALBERT TODY (opa) kaa ai Rachel rizka juniarty.

Tepotowo'a petia nokonoo:

$\begin{array}{ll}\text { Olo } & \text { :olo ko aso (senin) } \\ \text { Tengala } & : 04 \text { maret } 2019 \\ \text { Jaa } & : 18.00 \text { wundoolo (jam 06.00 sore) } \\ \text { Polangga } & : \text { air aha mami (keluarga sitti tody) } \\ \text { JL. Lasenba no. } & 165 \text { Wasuponda }\end{array}$

Ooto onie mpompohawe mami ndoio ikito lowo. Se'elunokupehawe komiu aroa mo'unde

Tabea mami,

Sitti tody

Sementara untuk variasi santai merupakan variasi bahasa yang digunakan dalam situasi tidak resmi untuk berbincang-bincang dengan keluarga atau teman karib atau percakapan dalam kehidupan sehari-hari. Dalam situasi, ini penutur mengunakan bahasa halus dan kasar yang disesuaikan penggunaannya dengan konteks dan lawan bicara. Dalam keseharian penutur bahasa Padoe terkadang menggunakan bahasa Padoe dan juga bahasa lain, karena keseluruhan dari masyarakat ini menguasai lebih dari satu bahasa. Dalam penggunaannyapun tak memiliki aturan yang khusus, asalkan telah memenuhi aturan etika dalam berbahasa.Contohnya dalam keluarga dimulai dari aturan berbicara anak yang tidak boleh menyela orang tua, tidak boleh menggunakan bahasa kasar, dan berperilaku santun.Untuk berbicara antara suami istri menggunakan bahasa yang baik dan sopan.Sedangkan untuk interaksi dengan teman sejawat atau teman sebaya penggunaan lebih bebas dan tidak memiliki aturan khusus.

\section{Kata yang pantang untuk diucapkan}

Ada beberapa kata yang tidak boleh diucapkan pada kalangan tertentu , namun boleh diucapkan bila kata-kata itu telah mengalami perubahan makna karena konteks dan situasi tertentu. Contonhnya kata "lahu"pada ujaran dibawah ini

"eh lahu mu.." (informan 3)

(eh, anu mu)

Bila ujaran ini diujarkan pada situasi tegang pada perkelahian atau pada variasi bahasa santai maka arti dari kata "lahu"akan bermakna negatif yaitu penghinaan. Dan terlebih lagi bila diucapkan oleh anak-anak kepada orang tua.

"eh lahu inderioke iiko" (informan 3)

(eh, anakku kamu mau kemana) 
Ujaran diatas diucapkan oleh seorang istri kepada suaminya ataupun seorang ibu kepada anaknya, maka kata "lahu" di sini akan bermakna positif yakni suami atau anakku. Kata "lahu" ini diartikan sebagai "laki-laki".Namun permaknaan ini hanya berlaku pada variasi akrab, dan di ujarkan pada lawan tutur yang dikenal baik saja.Dalam memilih kata harus lebih berhati-hati dan sesuai dengan situasi, konteks dan dengan siapa kita berbicara, agar tuturan yang diucapkan tidak bermakna negatif yang dapat menimbulkan kesalapahaman antara penutur.

\section{Aturan berbicara dalam perbedaan status sosial}

Masyarakat Padoe juga memiliki aturan khusus dalam berbicara yang berkaitan dengan status sosial, akan tetapi seiring berjalannya waktu aturan ini perlahan mulai terlupakan dan tidak lagi digunakan.

\section{Simpulan}

Aturan berbahasa Padoe di masyarakat dilandaskan pada aturan etika, konteks, dan siapa lawan tutur. Dahulu bahasa Padoe memiliki aturan yang cukup kompleks namun dikarenakan perkembangan zaman, dan situasi di masyarakat saat ini secara perlahan mulai meninggalkan aturan ini. Perkembangan kosa kata juga terhambat kerena tidak ada dokumentasi dari para pendahulu serta berkurangnya penutur asli. Secara etnografi komunikasi peristiwa tutur yang terjadi pada masyarakat padoe tidak lepas dari konteks kebudayaan yang ada yang tercakup pada aturan atau norma berbahasa serta pantangan-pantanga kosakata yang tidak bisa diucapkan dalam kondisi tertentu. 
Jurnal Onoma: Pendidikan, Bahasa dan Sastra

ISSN 2443-3667 (print)

PBSI FKIP Universitas Cokroaminoto Palopo

ISSN 2715-4564 (online)

Volume 6 Nomor 1

\section{Daftar Pustaka}

Aslinda \& LeniSyafyahya. 2007. Pengantar Sosiolinguistik. Bandung: PT. Refika Aditama.

Bakry Suryadi.2017. Pemanfaatan Metode Etnografi dan Netnografi dalam Penelitian Hubungan Internasional.Global \& Stategis.Vol. 11.No. 1. Universitas Jayabaya. Surabaya.

Chaer Abdul dan Agustina Leoni.2014. Sosiolinguistik Perkenalan Awal. Jakarta: Rineka Cipta.

Fatchan Ach..2015. Metode Penelitian Kualitatif Pendekatan Etnografi dan Metnometologi untuk Penelitian Ilmu-IImu Sosial.Yogyakarta.Outbok.

Isyanto \& Novianti.2018. Etnografi Komunikasi Komunitas yang Kehilangan Identitas Sosial dan Budaya di kabupaten Cilacap.Jurnal Kajian Komunikasi. Vol. 6.No. 1.Universitas Jendral Soediman. Bayumas

Sumarsono. 2014. Sosiolinguistik. Pustaka belajar: Yogyakarta. 